\title{
Chinese Islamic Ceramics at the Museum of Niujie Mosque "An analytical Study"
}

\author{
Hamada Hagras \\ Islamic dept., Faculty of Archaeology, Fayoum Univ. \\ hmh00@fayoum.edu.eg
}

\begin{abstract}
This paper aims to study, publish and examine a collection of new seven ceramic wares of the Museum of Niujie Mosque in Beijing, which have never been studied before. This collection dates back to the Ming-Qing periods. This study tries to explain the technical methods and raw materials of these pieces, as well as decorations, which were characterized by harmony, richness, and consistency between shape and content, also tries hard to understand the intellectual and symbolic aims of the Chinese Muslim artists. As well as exploring the political circumstances during that time, which certainly led to the emergence of this type of Chinese porcelain, and revealing the common features of Chinese Islamic ceramics. After reviewing the shapes, decorative patterns and scripts, it was concluded that the appearance of this type of porcelain is a result of the influence of local Islamic culture. In addition, it is a logical demand for the economic requirements, as large quantities of this type of porcelain were exported to the Islamic world. On the other hand, Chinese ceramics with Arabic scripts are evidence of Islamic heritage that was formalized by official kilns witch controlled by the Chinese court during the Ming and Qing periods. The study is a new value on Islamic arts in the Far East, and it also adds an important value in the field of Islamic arts.
\end{abstract}

Keywords: Chinese Muslims, Ceramic, Scripts, Inscriptions, Porcelain, Celadon.

\section{Introduction}

Muslim historians have preserved texts that monitor Chinese skills in arts; Sulaiman alTajir ( $9^{\text {th }}$ century) in which he reported that "the Chinese people are the best people in the arts, and every work in which no other nation can compete with them" (al-Tajir \& alSirafi, 1994), Ibn al-Faqih (10 ${ }^{\text {th }}$ Century) referred to the mastery of industries in China, saying "the Chinese People are proficient in the industries (Ibn al-Faqih, 1996), And alMarwazi (d. 1124-1125), quoting "They are the most skilled people in handicrafts and none of the nation's rivals them" (Al- Marwazi, 1942). As for Ibn Battuta (d. 1369), he documented the skill of the Chinese during his travel to China, in which he reported that "The people of China are the most skillful artificers" (Ibn Battuta, 2010). We quote alNuwayri (d. 1333) as saying "The Arabs refer to any glass curio as Chinese because of the skill of Chinese in making curios" (al-Nuwayri, 2016).

However, Chinese ceramics had been emerged over 3,000 years ago, and began exporting during the Han Dynasty (206 BC- 220 AD) to West Asia via the road later known as the Silk Road. Chinese ceramics found a way into the Arab region during the first century BC (Goffriller, 2014). The Tang Dynasty (618-907) was the strong start of its export abroad (Cooper, 2010). It is worth noting that Chinese ceramics had been known in 
Islamic countries since the Tang Dynasty, such as Iraq, the Persian Gulf (Lin, 2008), Iran, Yemen, and the eastern coast of Africa (Somalia and Madagascar) (Uthmān, 1990), as well as found significant Chinese ceramic pieces in the excavations of Fustat, Egypt, in 1964 AD (Kubiak \& Scanlon, 1973), also Samarra excavations in Iraq (Mei, 2003), in addition to the fact that among the Fatimid treasures large quantities of Chinese ceramics (Hassan, 2014), as well as some the Chinese coins found in the city of Dhofar (Uthman, 2000).

There is no doubt that Chinese ceramics have been well admired by Muslim potters as well as highly appreciated (Te-k'un, 1984); it has gained great fame and has been known to historians from relatively early periods; the first mentions of Chinese porcelain were in 851 AD during the Tang dynasty by the Arab traveler Sulaiman al-Tajir ( $9^{\text {th }}$ century) (Temple, 2007), who recorded that "They [Chinese] have a very fine clay with which they make vases which are as transparent as glass; water is seen through them" (alMuraikhi, 2005). Both of Ibn Khordadbeh (d. 912 AD) and al- Marwazi (d. 1124-1125) also indicated that Muslim merchants were primarily seeking to bring Chinese clay (Ibn Khordadbeh, 1992) (Al- Marwazi, 1942). During his trip to China; Ibn Battuta did not ignore the indicting to the quality of Chinese pottery, saying "Chinese pottery is made only in the city of Zaitun [Quanzhou] and in Sin Kalan [Guangzhou] ....It is the most superb kind of pottery" (Ibn Battuta, 2010)

Needless to say, Islamic ceramic was influenced by its Chinese counterpart, as its ancient traditions inspired Muslim potters and imitated it by simulating their shapes, colors, and decorations. Also, they produced Islamic ceramics influenced by Chinese ceramics, such as Iranian ceramics in Nishapur (era of Caliph Harun al-Rashid 786-809 AD) which is the oldest evidence on the Muslim imitation of Chinese ceramics (Hassan, 1990), similarly, Samarra and Egyptian ceramics in the Fatimid era (Husayn, 2010), where examples were found in the excavations of Fustat (Kubiak \& Scanlon, 1973), as well as Mamluk ceramics (Scanlon, 1984), and Turkish ceramics (Denny, 1974).

\section{The Niujie Mosque}

The Niujie Mosque is located in the Niujie Street of Beijing's Xicheng District, it is the oldest mosque in the Chinese capital, Beijing. The initial construction was in 996 during the Liao Dynasty (916-1125) and northern Song Dynasty (960-1127). The mosque was built by Sheikh Nasr al-Din bin Guam al-Din. Throughout its history, the mosque has complied with many of the reforms and expansions that occurred to it. During the Ming period; it was one of the four official mosques in the capital city. The museum of the mosque is located on the eastern side and contains many artifacts of Islamic art in China (Wahby, 2000) (Tong-Xun, 2003) (Steinhardt, 2008) (Hagras, 2019).

\section{A descriptive study}

The Museum of Niujie Mosque preserves seven ceramic artifacts that have never been studied, this collection varied between porcelain and celadon. As well as multiple dates; 
as some date back to the Ming Dynasty, others date back to the Qing Dynasty. It is worth mentioning that all objects of the collection not have identification or accession numbers, and is not cataloged.

Piece No. (1)

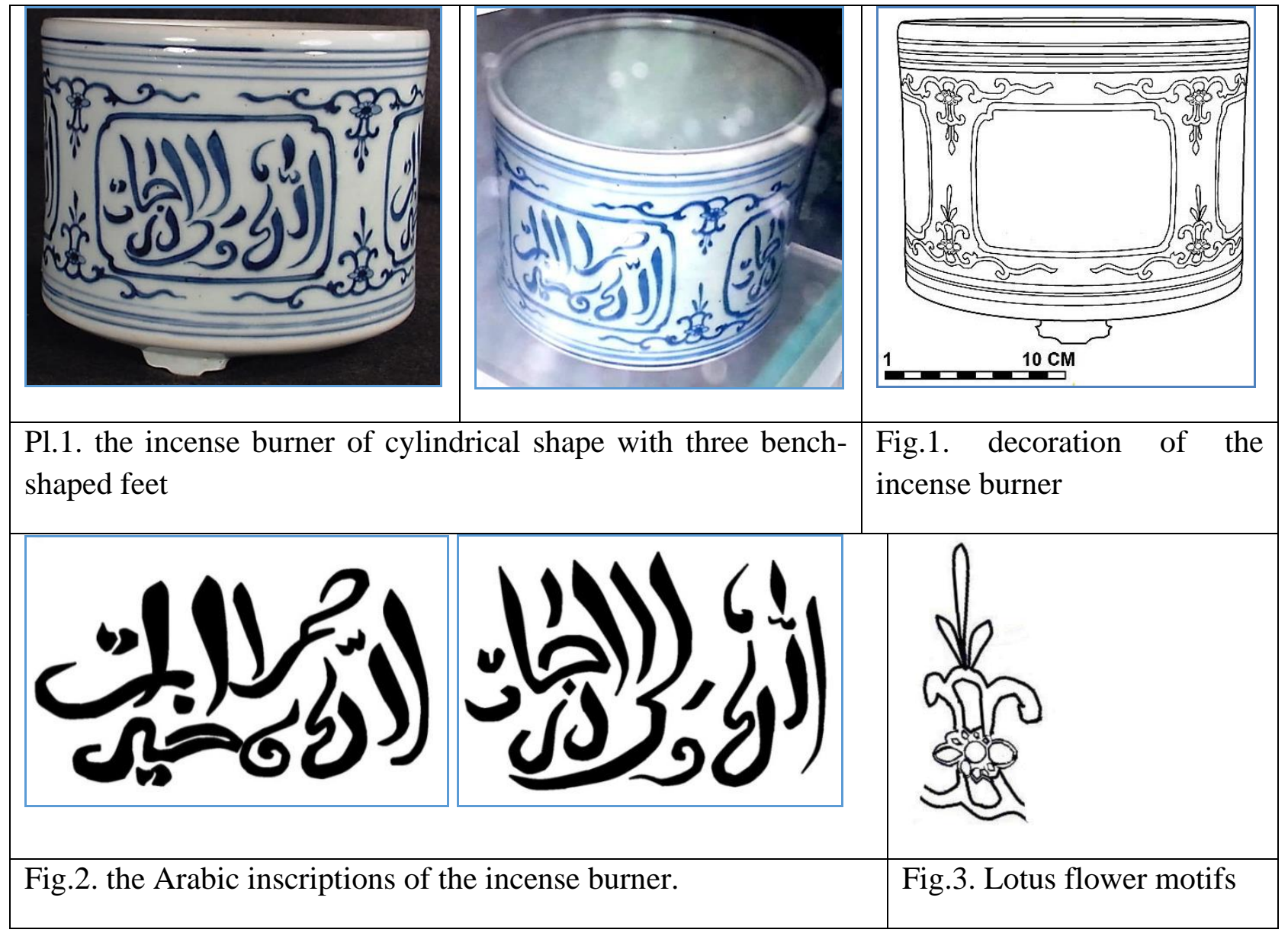

Type: incense burner

Material: Porcelain, blue and white

Dimension: Height $16 \mathrm{~cm}$, diameter $19.5 \mathrm{~cm}$.

Date: the Ming Dynasty, reign of The Emperor Zhengde, (1505-1521 A.D.)

\section{Description}

A blue and white porcelain incense burner, a cylindrical form based on three cloud feet (Pl.1- fig.1). It is framed in the upper and lower edges by four colored lines in blue, and the space between the upper and lower lines is decorated with four Arabic inscriptions on the outside, one on each. A pair contained the inscriptions read "الله ولي الدرجات" (Allah is the Guardian of the ranks), while the other pair contained inscriptions read " الله ولي "Al الخيرات" (Allah is the guardian of the goodness) (fig.2). Both Arabic calligraphy were applied the style of the Sini Thuluth script. Space between the inscriotions is decorated with Lotus flower (fig.3). A similar piece in the Wong collection bears a four-characters mark of the Zhengde reign in underglaze blue within a concave circle (Phoenix-Art- 
Museum, 1982), this shape of the incense burner was a common during Zhengde reign (Pl. 2). Gayer Anderson Museum in Cairo also preserves a similar shape (al-Wakil, 2010) (Pl. 3).

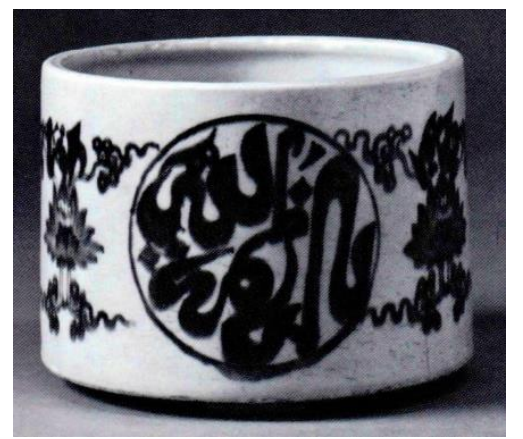

Pl.2. Ming incense burner in The Wong Collection (Phoenix-Art-Museum, 1982).

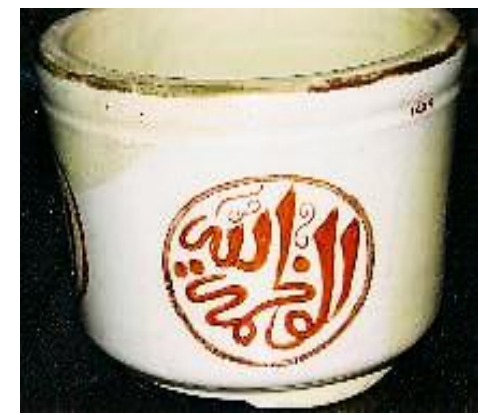

Pl.3. Ming incense burner in Gayer Anderson Museum (al-Wakil, 2010).

\subsection{Piece No. (2)}
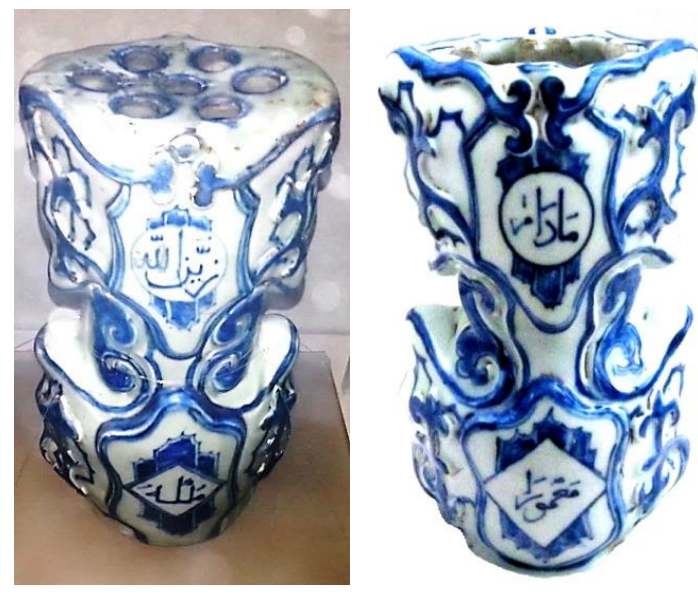

Pl.4. Blue and white vase.
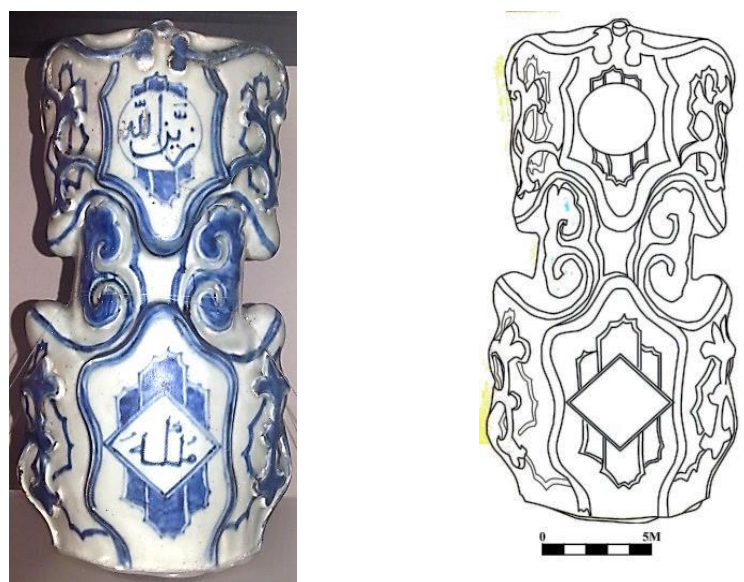

Fig.4. Decoration of the vase.
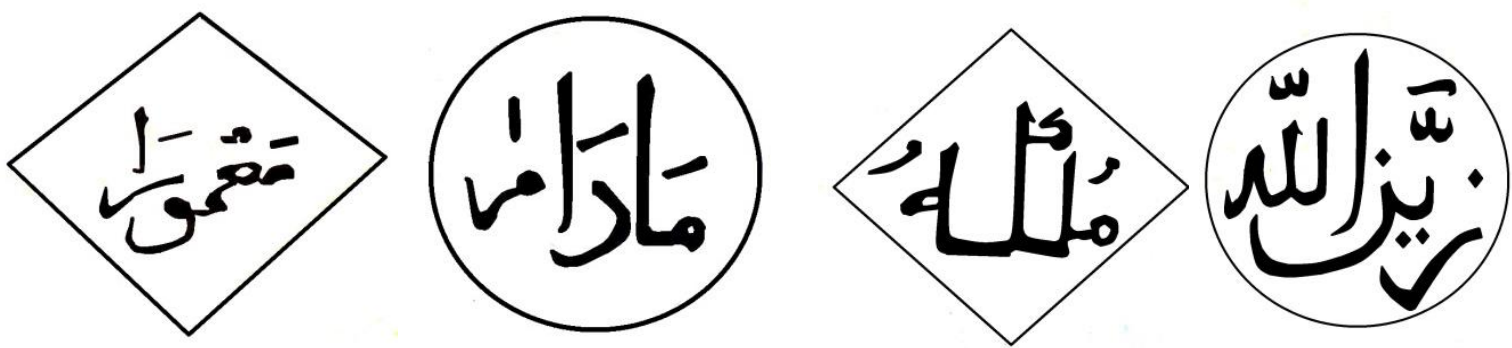

Fig.5. Inscriptions of the vase. 
Type: Vase.

Material: Porcelain, blue and white

Dimension: Height $23 \mathrm{~cm}$, the outer diameter is $11 \mathrm{~cm}$, the inner diameter is $8.5 \mathrm{~cm}$.

Date: the Ming Dynasty, reign of The Emperor Zhengde, 正德, (1505-1521 A.D.)

\section{Description}

The vase is incomplete where it can be seen that the lower substrate of the vase is missing (Pl.4- fig.4). The masterpiece is cylindrical in shape, and the body has non-straight lines. The vase in its shape differs from the traditional vases in which the body follows the cylindrical shape with a round base and a bulging body on the top and ending with a long neck ending with a nozzle The vase nozzle is hollowed out with seven finger-sized holes; a hole at the center surrounded by six other finger-sized hole. These perforate are used for the purpose of inserting flower stems in them, so that the branches of flowers are kept in designated places, in addition to allowing water to be poured into it. The body is divided into three parts: the upper and lower are more prominent than the middle, the upper part is decorated with two single roundels each containing further Arabic inscriptions, while the lower part is decorated with a a diamond-shaped panel with Arabic script, we can read the entire writings as follows "زين الله ملكه ما دام معمور" (Allah prettify his sovereignty as long as it maintained) (fig. 5). It is noted that the motifs on the rhombus side complied with the traditions of Chinese motifs, such as the trilogy leaves known as Ruyi, and the middle section was decorated with motifs composed of Chinese clouds.

It is worth noting that the Amsterdam Museum has a similar vase, but it is in full parts; its base has Chinese inscription dating to reign of the Emperor Zhengde of the Ming Dynasty. The dating formula of the inscription is a standard complete version of Zhengde; a six-character Zhengde reign mark, “大明正德年制”, Inscription transliteration: "Da Ming Zhengde Nian Zhi". Inscription translation: "Made in the Zhengde reign of the Ming dynasty". Accordingly, the vase in the collection of the Niujie Museum - the case of the study - can be dated to the reign of the Zhengde (Pl.5).
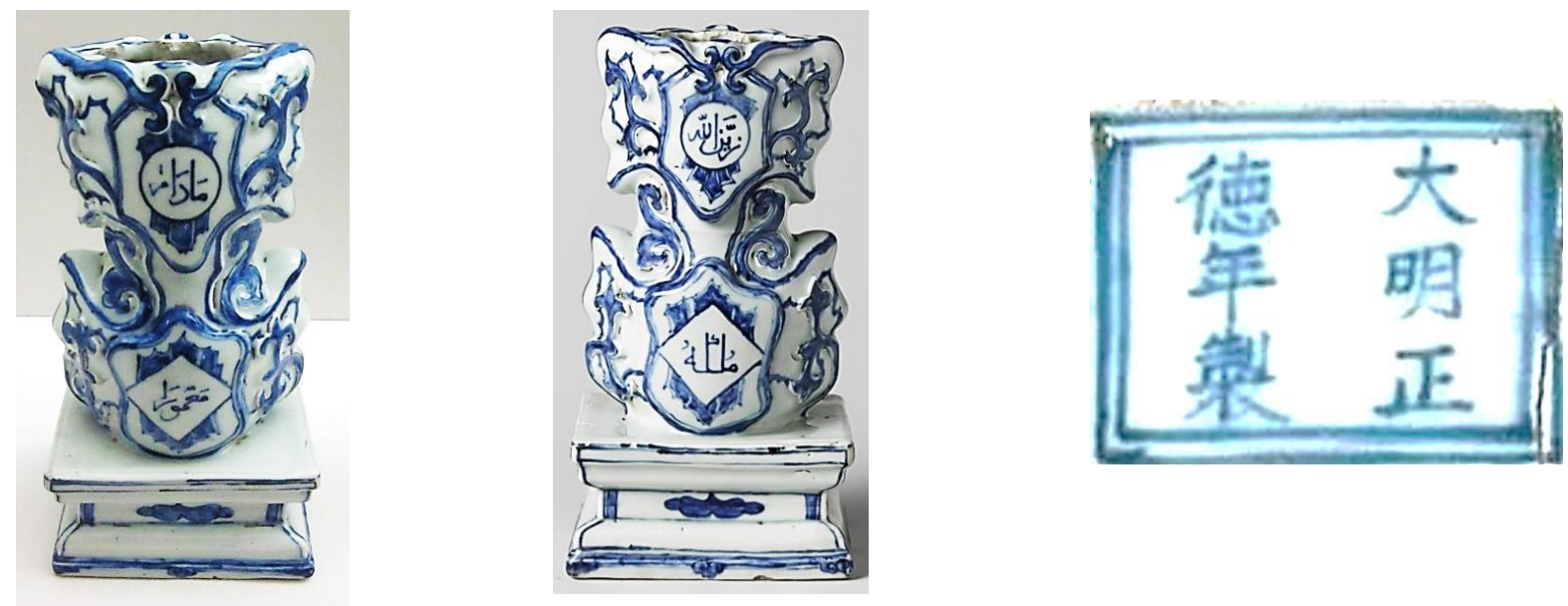

Pl.5. A vase of Amsterdam Museum 


\subsection{Piece No. (3)}
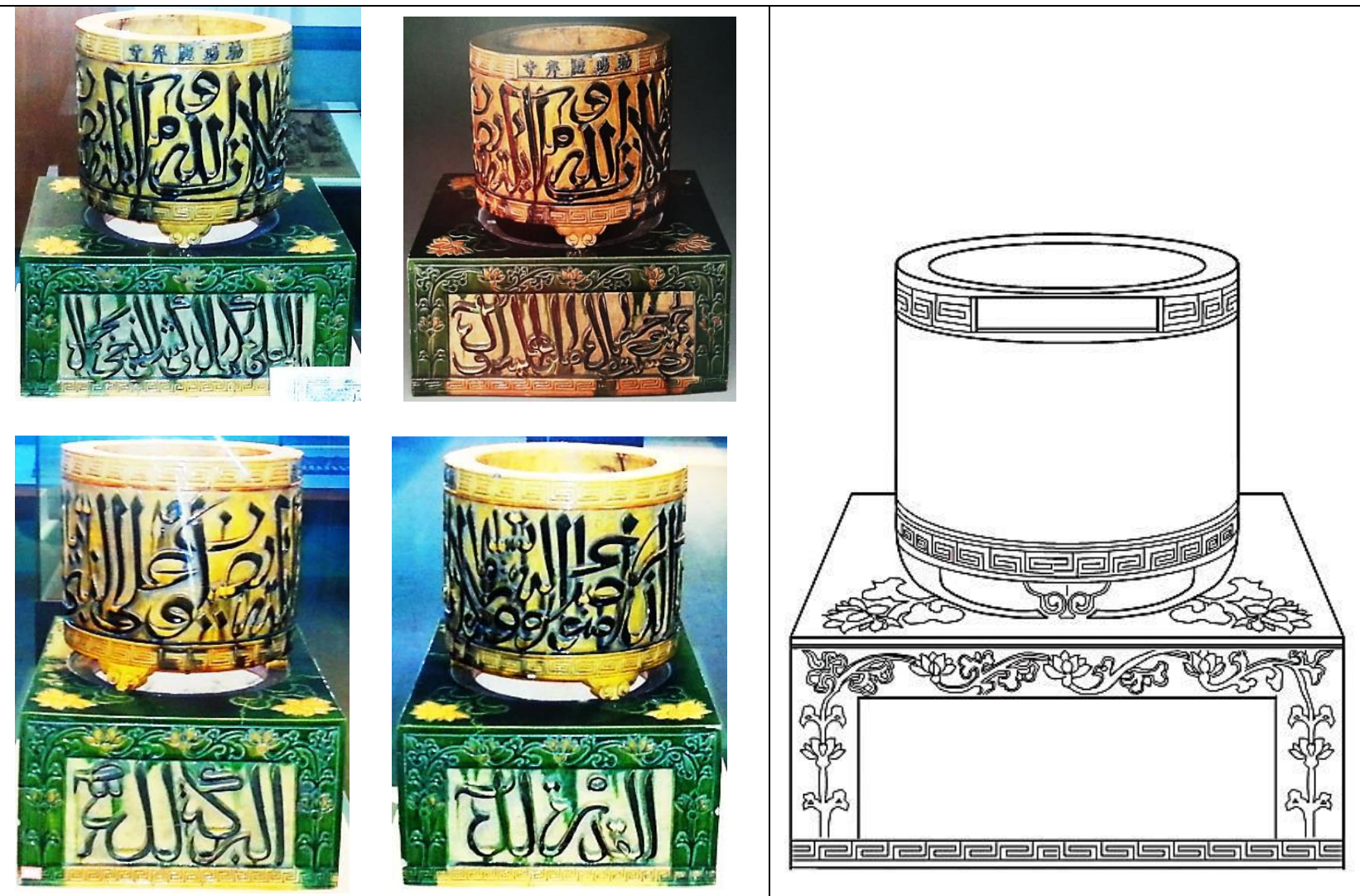

Pl.6. Celadon incense burner

Fig.6. decoration of the incense burner

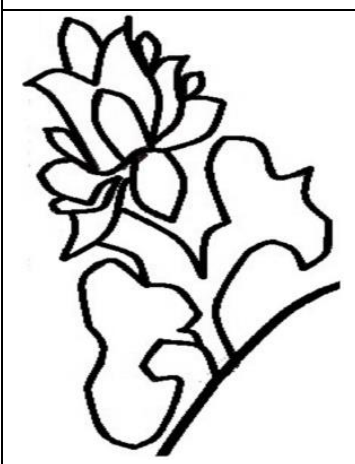

Fig.7. Lotus Patterns

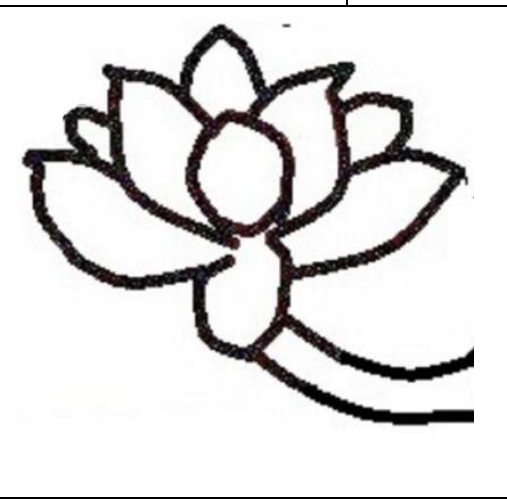

Fig.8. Ruyi Pattern 


\section{Chinese Islamic Ceramics at the Museum of Niujie Mosque "An analytical Study"}

Type: incense burner

Material: green celadon

Dimension: Height $56 \mathrm{~cm}$, the incense burner consists of two parts: the base is a cube with a base length of $38 \mathrm{~cm}$ and a height of $31 \mathrm{~cm}$, while the upper part is a cylindrical shape with a height of $25 \mathrm{~cm}$ and a diameter of $25 \mathrm{~cm}$.

Date: the Qing Dynasty, the 33th year of reign of The Emperor Kangxi, 康熙, (16611722 A.D.), dating to 1698 A.D.

\section{Description}

The incense burner consists of two parts: the upper is a cylindrical well, which is based on three cloud feet, while the lower part is in the form of a cube (Pl.6- fig.6). The censer is decorated with Lotus Ruyi patterns (figs.6, 7, 8), also decorated with inscriptions in Arabic according to the type of sini thuluth script. As for the contents of these

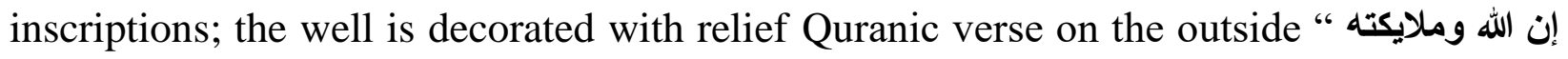
يصلون على النبي يا أيها الذين أمنوا صلوا عليه وسلموا تسليما" (Allah and His angels send blessings on the Prophet: $\mathrm{O}$ ye that believe! Send ye blessings on him and salute him with all respect) (The Holy Quran, Al-Ahzaab, 56). The lower part is decorated with four biblical spaces confined within rectangles framed by a decorative ribbon consisting of branches

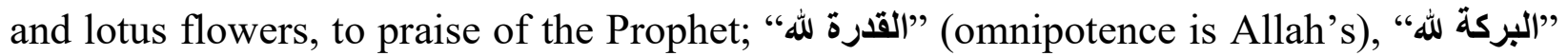

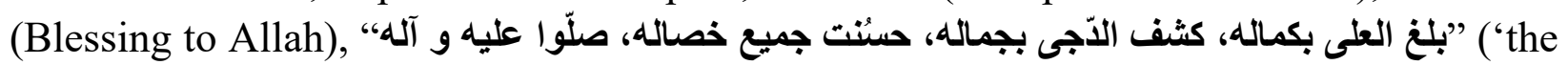
prophet' attained eminence by his perfection (fig.9). the darkness was lifted by his beauty. Lovely are all of his qualities. Blessings upon him and his family), that is Arabic poetry in praise of the Prophet, was quoted from The Gulistan of Shirazi (1210-1291 A.D), the Persian poet (Shirazi, 2012). The upper edge of the well contains Chinese inscriptions “賜勅禮拜寺” (fig.10), the inscription transliteration: “ci chi libaisi”, inscription translation: "Imperial decree or grant to the mosque". The base is marked with Kangxi reign mark; “康熙戌寅年許碧膨脹國欲造” (fig.11). The inscription transliteration: "Kangxi xuyin nian xu bi pengzhang guo yu zao". Inscription translation: "Kangxi reign, the year of Xuyin, made by order of the emperor", is dating to 1698 A.D. 

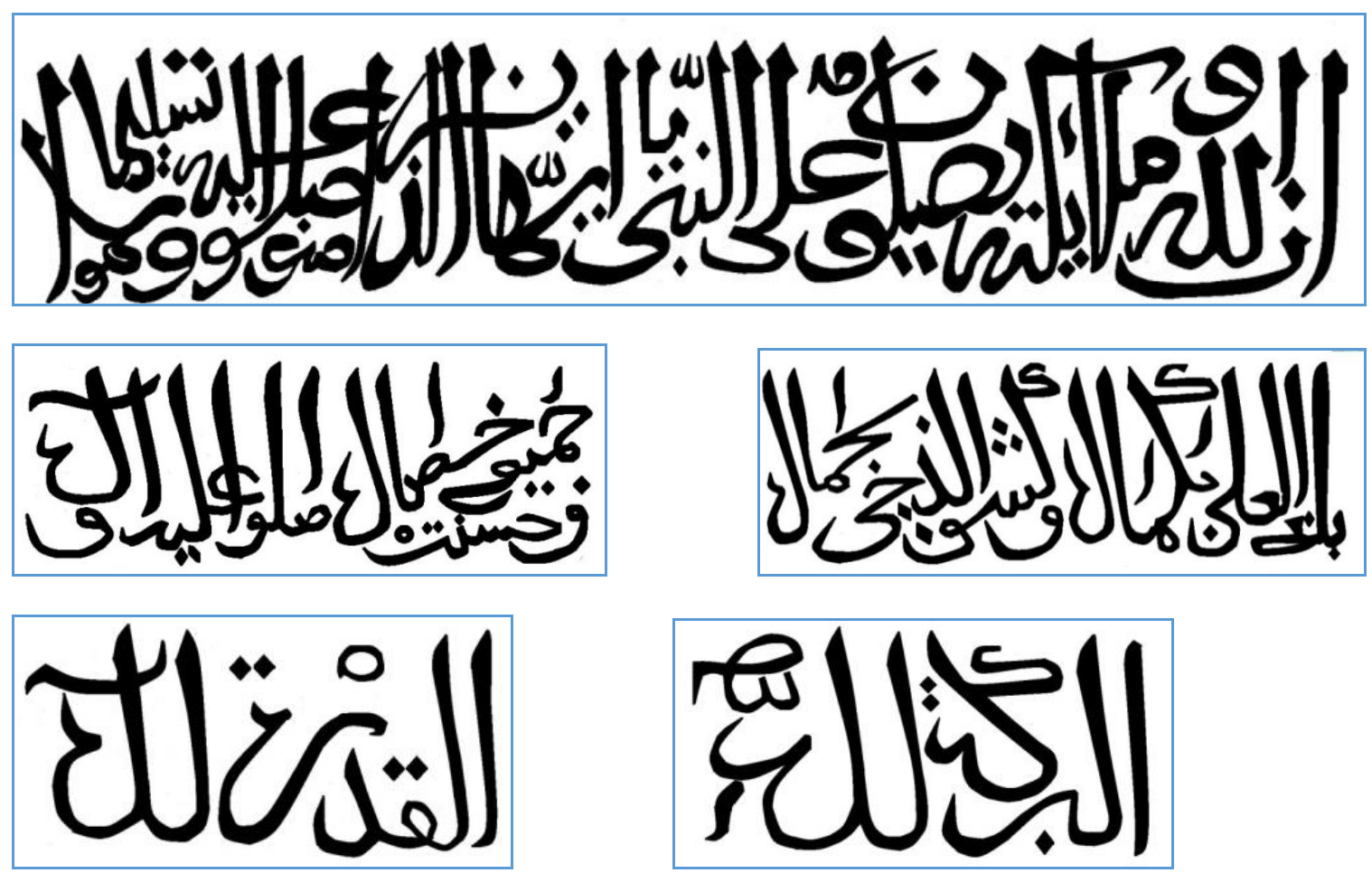

Fig.9. Arabic inscriptions of the incense burner
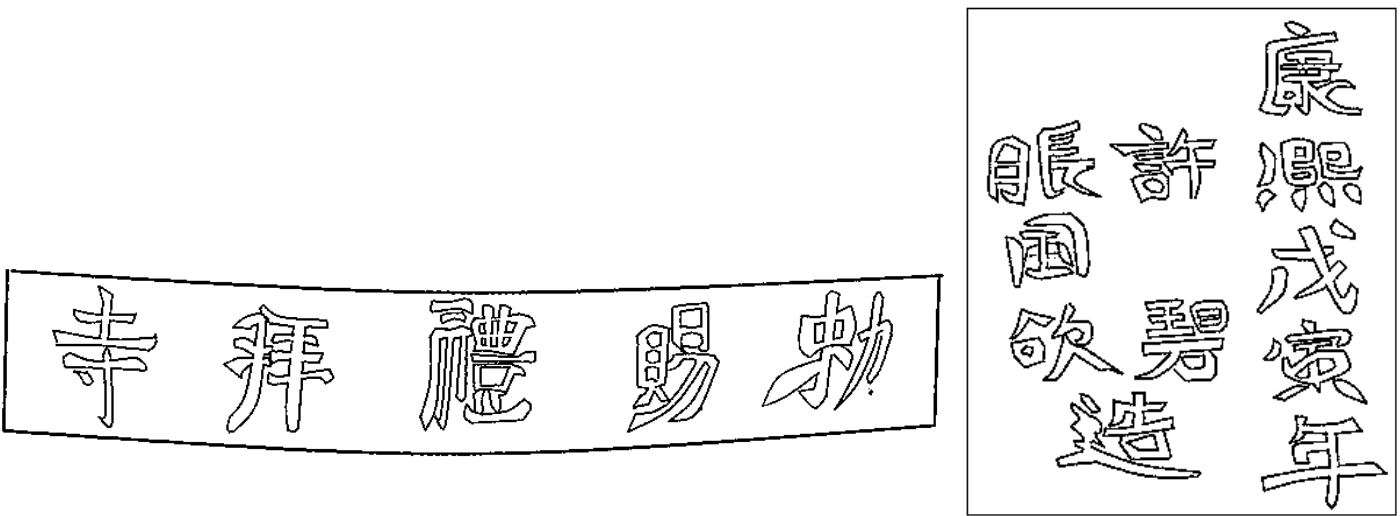

Fig.10. Chinese inscription of the well.

Fig.11. Kangxi reign mark

1.3. Piece No. (4) 

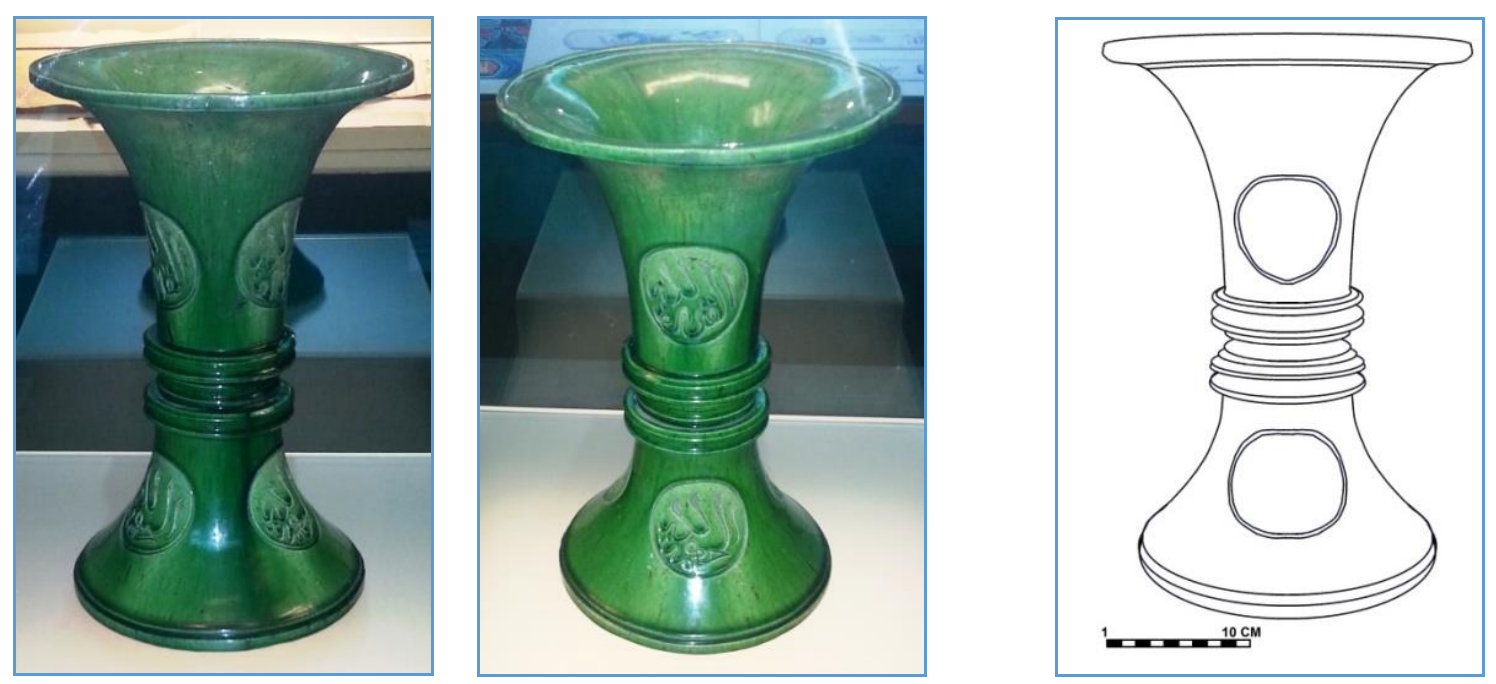

Pl.7. Celadon vase

Fig.12. decoration of the vase.
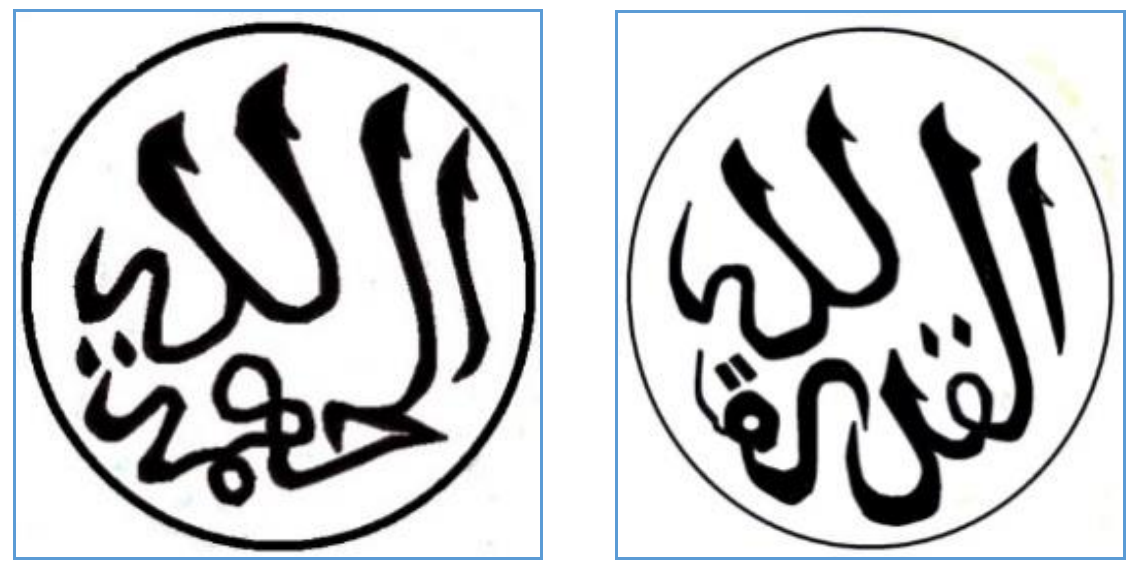

fig.13. Arabic inscription of the vase.

Type: Vase

Material: green celadon

Dimension: Height $40 \mathrm{~cm}$, the diameter of the nozzle is $26 \mathrm{~cm}$, and the diameter of the base is $23 \mathrm{~cm}$.

Date: Qing Dynasty, Kangxi period.

\section{Description}

This vase applied the form of gu ware, 解, which was one of the most common, dating back to the Shang and Zhou dynasties, was crafted with bronze (Deydier, 2015). Its shape is tall and slender, with a base that tapers to a slim center section before widening again into a trumpet-like mouth, little wider than the base (Pl.7- fig.12). In general form, the vase is divided into three parts: the middle part is two prominent bars that surround a low 
tape, while the upper and lower parts are very similar except that the upper part is more elongated. It is decorated on two opposing sides with partially vocalized Arabic inscriptions in sini thuluth script in one roundel, we can read the inscription as "القدرة لله (omnipotence is Allah's), “الحكمة لله" (Wisdom to Allah) (figs. 12, 13).

\subsection{Piece No. (5)}
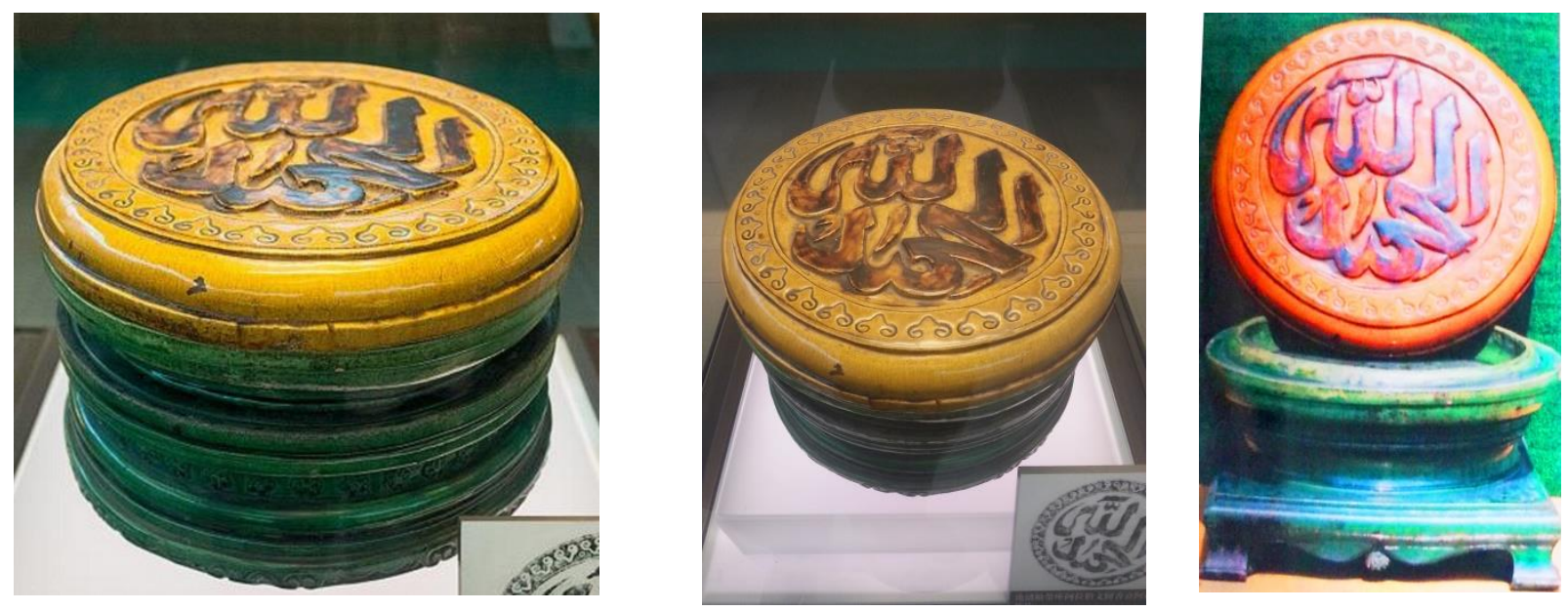

Pl.8. Celadon incense box
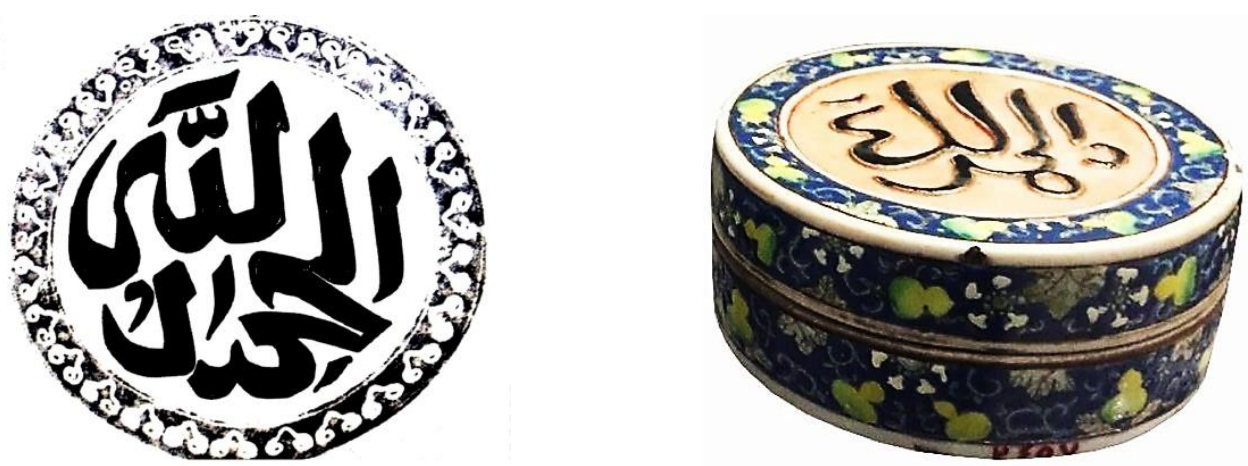

Fig.14. Arabic inscription of the Pl.9. A Qing box (Islamic Art Museum in Cairo) box.

Type: Incense box

Material: green celadon

Dimension: Height $29 \mathrm{~cm}$, cover diameter $40 \mathrm{~cm}$, base diameter $33 \mathrm{~cm}$.

Date: Qing Dynasty, Kangxi period.

Description

Of circular form with straight sides, it is divided into three prominent sections, confined to shallow areas devoid of decoration, except the lower one, where they are decorated 
with five-petal plum flowers (Pl.8). The slightly domed cover painted with a center medallion enclosing Islamic inscriptions encircled by Ruyi motifs, its text is "الحمد لله" (Praise is to God) (fig.14). A similar piece with motifs and inscriptions preserves in the Islamic Art Museum in Cairo (Pl.9).

1.5. Piece No. (6)

Fig.16. Arabic inscription of the incense burner the

Type: incense burner

Material: yellow celadon

Dimension: the height is $22 \mathrm{~cm}$. The diameter of the nozzle is $38 \mathrm{~cm}$, and the base diameter is $23 \mathrm{~cm}$.

Date: Qing Dynasty, Kangxi period.

Description

Without overlap the outlines of the design, well carved, clear, subtle, distinct, and the shape is uniformly proportioned. The burner has a shallow body, of a shallow ware, broad wide cavetto, with a straight opening lip, raised on a slightly raised round base (Pl.10- fig.15). On both sides of the burner, there is a handle in the form of a floral leaf integrated with the body and decorated with a pin reinforced in a rectangular piece with an ornament on either side of which hangs in the form of traditional Chinese curtain folds (fig.17). All decorations reserved in green under glaze base color. The Exterior is 
decorated on two opposing sides with partially vocalized Arabic inscriptions in sini thuluth script in one panel: "قال النبي عليه السلام" (The Prophet, peace be upon him, said), and "لا إله إلا الله محمد رسول الله" (There is no God but Allah, Muhammad is the Messenger of Allah) (fig.16).

\subsection{Piece No. (7)}

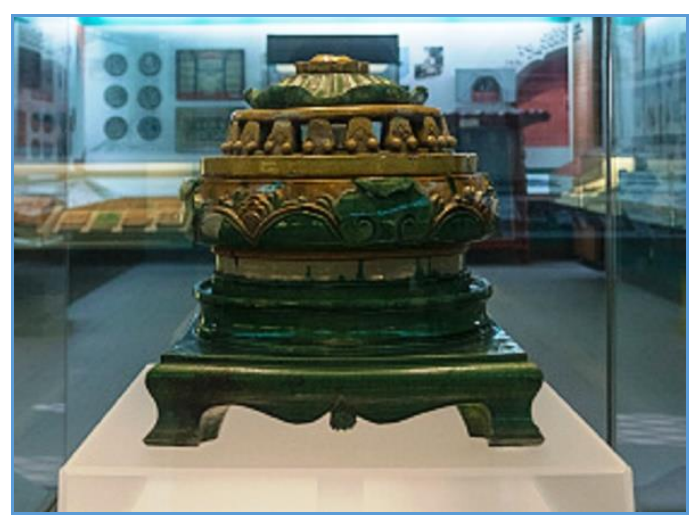

Pl.11. Celadon incense burner
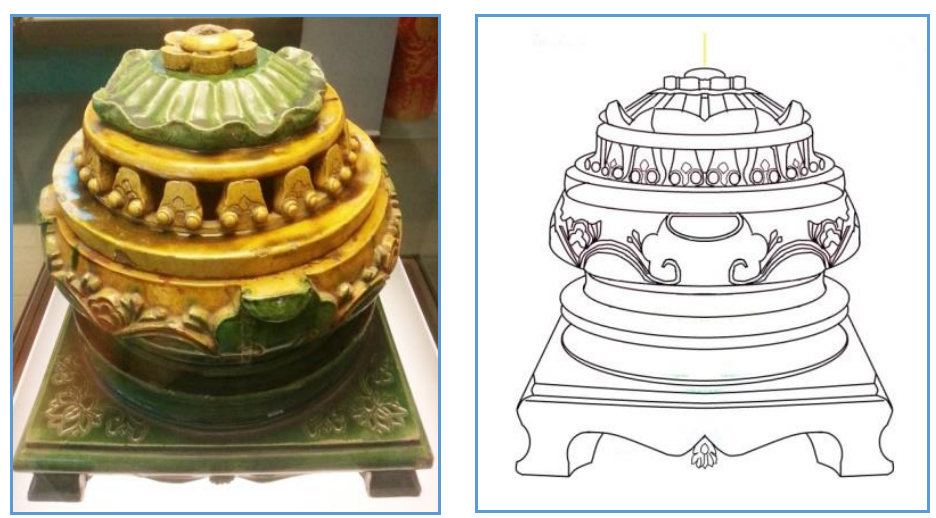

Fig. 18. Decoration of the incense burner

Type: incense burner

Material: yellow celadon

Dimension: The upper part: it is $26 \mathrm{~cm}$ high, $30.5 \mathrm{~cm}$ in diameter, while its base diameter is $27.5 \mathrm{~cm}$. The height of the cap is $13 \mathrm{~cm}$, and the diameter is $29 \mathrm{~cm}$. Bottom part: 13.5 $\mathrm{cm}$ high, which is a side length of $36.5 \mathrm{~cm}$.

Date: Qing Dynasty, Kangxi period.

\section{Description:}

The type of the burner follows the Lotus-Censer type, 莲花纹圓香熏. The cylindrical body is swollen with a round, flat-bottomed nozzle, anchored on short feet (P1.11- fig.18). The body is decorated in a way known as the colored sleeves, 琉璃袖壁. The body is also decorated with six petals of the lotus flower that intertwined with lotus leaves, while the domed cover is decorated with an openwork ribbon of flowers and Ruyi motifs, known as 器身浮雕花卉纹 (Liu-Rushui, 2004) (Zhongguo-lishi-bowuguan, 1991). The base has a square of four pillars, the base contains circular support for the oven, and there are a group of lotus patterns engraved on the four corners.

\section{DISCUSSION}

\subsection{Types of ceramic}

\subsubsection{Chinese blue and white porcelain}

Blue and white porcelain is known to the Chinese as 青花, 'Blue flowers/patterns'. Archaeologists differ in determining the emergence of blue and white porcelain in China; 
some believe that it appeared in the early Ming period, while others see it as dating back to the Yuan dynasty (Medley, 1989) (Kessler, 2012); others go further; they believe that its appearance dates back to the Han dynasty (206 B.D-220 A.D) (Kelun, 2004). In the Tang Dynasty (618-907 AD), porcelain developed gradually. This type of porcelain appeared to be painted with a cobalt oxide, which was used in the Arab region during the Abbasid era (Medley, 1989); the increasing trade between China and the Muslim world during the Tang era led to the development of Chinese Porcelain, where cobalt reached China from Mesopotamia through Persia (Wood, 1999). Tang's porcelain was transparent and white (Vainker, 1991). During the Song dynasty, the porcelain industry became highly organized, during which time it produced a good amount of porcelain pieces (Temple, 2007). By the Ming Dynasty (1368-1644 AD), porcelain pots were exported to Europe, and carried by Portuguese and Dutch merchants (Te-k'un, 1984).

However, the Yuan Dynasty marks the strong start of porcelain, while the 14th century is the strong start of Chinese expansion of blue and white ceramics; The Chinese were able to develop their own industrial methods. And that is by drawing the cobalt below the transparent layer (al-Wakil, 2010). Its manufacturing capital was Jingdezhen (Vainker, 1991) (Wood, 1999) (Rawson, 2007). In fact, the decoration with cobalt was neither Jingdezhen's discovery nor Chinese at all; Rather, it was known - as mentioned earlier in the Islamic world; it was became popular in Islamic ceramic during the Abbasid Caliphate (Wood, 1999). In the late Tang Dynasty, the Gongxian region in northern China was the first to use the cobalt oxide and moved to Longquan during the Northern Song Dynasty (Wood, 1999).

Porcelain is a type of Chinese porcelain made of a special type of pure clay that withstands high temperature when burned; it composed of two main substances: kaolin (is a mineral that follows Kaolinite and is characterized by withstands high temperatures, its chemical composition is Al2Si2O5 (OH)4) (Brindley \& Robinson, 1946) (Goodyear, 1961) (Pohl, 2011) and Petuntse (is a chemical with many names such as porcelain stone and pottery stone, which is concentrated in Jiangxi province in south-east China) (Rawson, 2007) (Vainker, 1991) (Kerr, et al., 2004). However, these two materials are mixed together in varying proportions as a preliminary stage. It is followed by the wine phase, followed by the melting stage at a high temperature of 1280 degrees Fahrenheit to change their shape to a glazed solid (Macintosh, 1994) (Cresswel, 1998).

Among the most important characteristics of porcelain are its delicate aspects and its lightweight when compared to other types of ceramics, is also characterized by resonant like metal, and it is dominated by white color with blue decorations; so these two colors were the most prominent characteristics (Marzouq, 1974). It is also distinguished by its hardness, durability, low thickness and ability to withstand shocks, and the quality of the glaze layer on it, which gained a special smoothness in its texture (Cresswel, 1998), that its smoothness is similar to glass (Denny, 1974). As for the method of decoration of blue and white porcelain; after drying, the wares will undergo some technical operations. it 
was once-fired: decorated with refined cobalt-blue pigment mixed with water and applied using a brush, it was coated with a clear glaze and fired at high temperature (Finlay, 2010).

\subsubsection{Chinese Celadon}

Celadon is denoting both wares glazed in the jade green color, it dates back to the Shang dynasty (1600-1050 BC) (Kelun, 2004). During the Tang dynasty (618-907 A.D), important cities emerged as major centers of celadon, such as Ningbo and Shaoxing (Kelun, 2004). Chinese Celadon found its way to the Islamic countries, where examples were found in the excavations of the Arab region and Persia (Hansman, 1985), and it was exported to East Asia and East Africa in the $11^{\text {th }}$ century AD (Li \& Cheng, 1996).

The most important characteristic of Chinese Celadon is that its glaze is a layer known as ash glaze (Wood, 1999). It was made with a material that blends wood ash (coal dust) and clay (Osborne, 1975), as well as some limestone proportions, mixed with water (Vainker, 1991). This mixture is a cause of celadon gaining dark brown, green, gray, and olive color, depending on the proportions of the coal dust (Vainker, 1991) (Ford \& Impey, 1989).

\subsection{DECORATION}

The decorative elements of Chinese Islamic ceramics varied, as the artist decorated it with many elements, whether floral or geometric motifs, as well as inscriptions in Arabic and Chinese, which varied between religious and other texts.

\subsubsection{Floral decorations}

The floral motifs are the most common types of decoration used in the decoration of the collection, and are one of the most important subjects implemented on Chinese ceramics in general and closely related to it, due to the influence of artists in the diverse natural environment of Chinese territory. The artist used many floral motifs that are sometimes close to nature and sometimes modified, and have earned it harmony that added to the artwork a kind of beauty. The plant motifs in question were characterized by flexibility, harmony and repetition, and carried types of plant motifs such as plant branchestriangular leaves- arabesques, lotus and plum flowers, and Chinese Ruyi motifs. The floral branches form the stems, the base of the ornament from which one or many flowers emerge, in a streamlined or twisted and intertwined form, where the artist used them to fill in the blanks due to their flexibility and twisting. (Pls 1,4,6,11- figs 1,4,6,14)

\subsubsection{The lotus Flowers}

The Muslim artist was influenced by lotus flowers that spread in Chinese art with influence from Buddhist art (Hejing-Jing \& Ge-Xiao, 2010). It is worth mentioning that China is one of the most civilizations used lotus flowers along with the ancient civilizations of Egypt and India (Chou, 1962). However, China's art was the most used 
and developed art of Lotus and was greatly associated with it. It seems that this is due to its benign symbolism in Chinese traditions, as it symbolizes innocence, peace, and fertility, as well as spiritual elegance and purity (Rezania, 2011). It is noted that the name of Chinese mosque is Qingzhonsisì, literally meaning "temple of purity", as well as the Islamic religion known as qingzhenjiao which literally means the religion of purity and serenity; it is the same meaning that denotes the symbolism of the lotus flower in Chinese arts; therefore, lotus flowers have spread widely in Chinese Islamic arts. (pls. 1,6,11- figs. $1,3,6,7)$

\subsubsection{The plum flower}

Plum is one of the most beloved flowers in China and has been depicted a lot in Chinese art throughout history (Welch, 2008). Each of the four seasons in Chinese culture symbolizes a flower; the orchid symbolizes spring, the lotus symbolizes summer, the chrysanthemum symbolizes autumn while the plum symbolizes winter (Heinrich, 2007). In addition, it symbolizes the new birth and longevity, as this flower is characterized by the fragrant scent that spreads in the winter (Cai, 2008). Hence, the plum came to symbolize perseverance and hope, as well as beauty, purity, and the passage of life (Welch, 2008). Confucian culture also used it as a symbol of the principles and values of virtue (Bartók \& Ronan, 1994). However, the greatest spread of plum flower on the arts was in the era of Emperor Kangxi (1661-1722 AD). It appeared on a box of celadon, dated to the era of Emperor Kangxi. (pl.8)

\subsubsection{Ruyi motifs}

Ruyi is one of the traditional decorations of Chinese art, and its general form is in the form of a floral leaf that maybe triple or five-headed (Li-Ganlang, 2003) (Min \& Daye, 1998). This decoration has been associated with Chinese arts since ancient times, and gradually evolved during the Tang Dynasty (618-907) and Song (960-1279 ), and it became of special interest during the Ming and Qing dynasties, serving as a mascot for good luck and spiritual serenity (Hung-Wei, 1998). (pls. 4, 8, 11- figs. 4, 6, 8, 14)

\subsubsection{Geometric motifs}

There are many patterns and forms of geometric motifs on this ceramic collection, and The Chinese Islamic arts have been dominated by the use of geometric motifs in the form of decorative frames and ribbons revolving around the floral motifs or inscriptions executed on the body of artifacts. Simple geometric figures were used in the decoration, such as circles, squares, rectangles, etc. In addition to that, the artist sometimes intentionally created other forms through the overlapping of these geometric shapes, and in most cases, the geometric motifs formed areas that contained plant and engineering motifs, in addition to the Arabic and Chinese writings; Where the artist intent on this desire to break the deadlock and give an aesthetic touch to the product on the one hand, and highlight the writings on the other hand, or in other words, the lines and geometric 
shapes represented the beginnings and ends of the subjects, decorative patterns, and inscription spaces. (pls. 1, 4, 6, 7 - figs. 1, 4, 6, 12)

\subsection{Inscriptions}

\subsubsection{Arabic Inscriptions}

It is well known that the use of inscriptions in the arts is the most prominent feature of both Chinese and Islamic arts, and the Arabic writings and arabesque motifs appeared on Chinese ceramics since the Yuan dynasty (Rawson, 2007). The Niujie collection is decorated with many Arabic inscriptions of Islamic religious contents; these kinds of products are made specifically for local Islamic societies in China or for export to the Islamic world. Pottery was of great importance to the Chinese court; the Ming dynasty relied on it to send it as diplomatic gifts abroad (Hsu, 1988), which supported Ming's fame beyond China's borders at the time (Dillon, 2018).

It is no secret to us that the Ming missions led by the Chinese Muslim leader Zheng $\mathrm{He}(\mathrm{d}$ 1433 or 1435 A.D.) to the Islamic world us that the missions led by the Chinese Muslim leader Zheng He to the Islamic world and the treasures and gifts such as gold, silver, porcelain, and silk that brought with him in his fleet, with the aim of establishing diplomatic and economic relations with them (Dreyer, 2006). Zhengde emperor of Ming (1506-1521) also sent an embassy to the Ottoman sultan Selim I (1512-1520), a collection of Chinese ceramics with Arabic inscriptions was among them, which are now preserved in the Topkapi Museum in Istanbul (Lion-Goldschmidt, 1978). In addition, porcelain was one of the gifts and treasures granted by the court to the elite and army leaders, among whom were an unlimited number of Chinese Muslims (Maming-Da, 2011). For example, the Chicago Field Museum has two bronze incense burners with Arabic and Chinese inscriptions that include the name of Emperor Xuande (1425-1435 A.D), and the name of one of the most prominent Muslim leaders, Wu pang-tso (Laufer, 1934).

The reign of Emperor Zhengde was the strong start to produce products bearing Arabic and Islamic inscriptions as a result of the Chinese Muslims leading the political class and that also are exported abroad have an important economic value that returned with huge profits on the Chinese court. It goes without saying that the Arabic inscriptions had a very important cultural connotation, on the one hand, indicating the spread of Islamic culture and its entrenchment in China on the one hand and that it is an important connotation that expresses an important class that occupied a great rank in the social pyramid of China during Ming court. However, these writings were executed within various geometric shapes, such as circles, squares, rectangles, and rhombuses in addition to the medallions, the purpose of this was to emphasize that Arabic writings are the main subject of decoration and that they are the desired goal through artistic work. The contents of the inscriptions on ceramic at the Niujie Museum are varied, and can be classified to Quranic writings, short message, religious writings, and Arabic poetry. 
The Arabic inscriptions carried out on the objects Niujie collection according to the naskh script and its derivatives, especially the one-thuluth and the sini thuluth scripts. Arabic calligraphy has played an important role in China since the arrival of Islam, and it is enough to know that the Mihrab square, maqsurha, of the Mosque of Niujie in Beijing contains the oldest Arabic inscription in Chinese mosques, dating back to the Yuan dynasty, and its lines are in Kufic and thuluth scripts. Sini script is a calligraphic style used in China for the Arabic script, and refers to any type of Chinese Arabic calligraphy. Chinese calligraphers not only inherited the types of Arabic scripts; Rather, but they developed a thuluth script. The sini script spread during the era of the Yuan Dynasty since the 13th century, and developed in particular during the Ming Dynasty. The sini is written in a flowing, wavy circular shape (Quenzer, et al., 2014), and its letters are characterized by the use of thick and pointed legs, where the legs were thick from the top and pointed from the bottom.

\subsubsection{The contents of the inscription}

The contents of the inscription varied on the ceramic at the Niujie collection; these contents can be restricted to Quranic verses, religious texts, praise texts, and Arabic

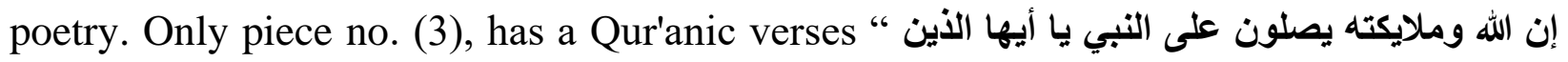
"أمنوا صلوا عليه وسلموا تسليما (Allah and His angels send blessings on the Prophet: O ye that believe! Send ye blessings on him and salute him with all respect) (Pl.6- Fig. 9).The religious texts appeared on piece no. (6), "قال النبي عليه السلام لا إله إلا الله محمد رسول الله (The Prophet, peace be upon him, said there is no God but Allah, Muhammad is the Messenger of Allah) (Pl.10- fig. 16). The praise texts were the common characteristic feature of the Chinese Islamic ceramic. The purpose of these inscriptions was to add Islamic character to the products, as well as to be used as amulets and symbols that bring goodness and blessing and protect from evil spirits and envy. The collection is decorated with six praise texts: "القدرة لله "(البركة لله" (Blessing to Allah) (Pl. 6- fig.9), "الحكمة لله "(Wisdom to Allah). (Pl.7- Fig. 13), "الحمد لله "(Praise is to

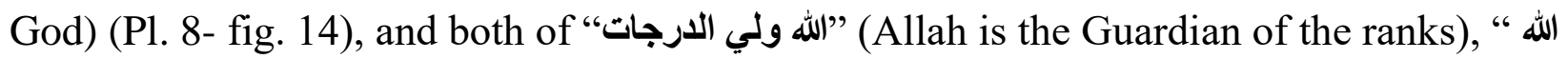
"ولي الخيرات" (Allah is the guardian of the goodness) (Pl. 1- Fig. 2). The Arabic poetry was also appeared; piece no. (3), was decorated with the poetry of Saad Al-Shirazi (1210-

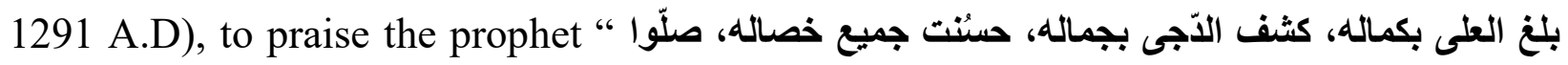
" عليه و آله (Shirazi, 2012) ('the prophet' attained eminence by his perfection. the darkness was lifted by his beauty. Lovely are all of his qualities. Blessings upon him and his family) (Pl. 6- fig. 9). 


\subsubsection{Chinese inscriptions}

Compared to Arabic inscriptions; Chinese did not play the same role as Arabic; as they were not used in a simple range, nor did they occupy the main areas of antiques, but were engraved on the bottom of the masterpiece base (Weng, 2011). Ceramic kilns adopted texts specifying the date of the industry to demonstrate that these ceramic pieces were made by certified craftsmen and that the kilns in which the porcelain was formed contained ovens under government supervision and under the eyes of the tiles. On the other hand, adding the Ming family name added more confidence to the ceramic products; the fact that its products are the best ever. The originality of the masterpiece was often emphasized by marking it with traditional Chinese characters, the content of which was often a mention of the history of the masterpiece making by registering the name of the ruling family, the name of the emperor and the year of manufacture (Aili, 2008). All the ceramics made during the reign of Emperor Zhengde (1505-1521) marked by a text that included six traditional Chinese characters "Made in the Zhengde reign of the Ming dynasty”, Da Ming Zhengde Nian Zhi，大明正德年製 (Wenjiang，1989) (Liangyou, 1992). (Pls.4, 5). The ceramic which was produced during the Kangxi reign (1662-1722) marked by “康熙戌寅年許碧膨脹國欲造”, “Kangxi xuyin nian xu bi pengzhang guo yu zao". Inscription translation: "Kangxi reign, the year of Xuyin, made by order of the emperor" (fig.11).

\section{CONCLOSION}

The study examined seven ceramic wares from the Ming and Qing dynasties, preserved at the Museum of The Niujie Mosque in Beijing, China. The study singled out many of the results through the descriptive and analytical studies. The study classified the types of ceramics in the collection by two types, and included white and blue porcelain "porcelain" and green porcelain "celadon".

Chinese Muslims made artistic and architectural treasures, including a large number of buildings and an unlimited number of applied artifacts such as ceramics, metals, textiles, etc., and introduced distinctive art, characteristics combining traditional Islamic and Chinese arts; they achieved a distinctive form that expressed their culture and identity. The abundance of artifacts reflects the presence and contribution of Muslims to Chinese civilization.

The study confirmed that the Chinese Muslim artist blended traditional Chinese motifs with the Arabic inscriptions of religious significance in a consistent way, aiming to serve the Muslim community in China as well as the great Islamic world by exporting these products, or using it as gifts accompanying the Chinese embassies to Islamic countries. Arabic inscriptions appeared in Chinese ceramics and were commonly used in the official furnaces of the Ming and Qing dynasties. 
The study proved that the Arabic inscriptions carried out on the objects Niujie collection according to the naskh script and its derivatives, especially the thuluth and the sini thuluth scripts. The contents of the inscriptions on ceramic are varied, and can be classified to Quranic writings, short message, religious writings, and Arabic poetry.

The contents of the inscription varied on the ceramic at the Niujie collection; these contents can be restricted to Quranic verses, religious texts, praise texts, and Arabic poetry. The praise texts were the common characteristic feature of the Chinese Islamic ceramic. The purpose of these inscriptions was to add Islamic character to the products, as well as to be used as amulets and symbols that bring goodness and blessing and protect from evil spirits and envy.

The Chinese inscriptions did not play the same role as Arabic; as they were not used in a simple range, nor did they occupy the main areas of antiques, but were engraved on the bottom of the masterpiece base. The artist used many floral motifs that are sometimes close to nature and sometimes modified, and have earned it harmony that added to the artwork a kind of beauty. The plant motifs in question were characterized by flexibility, harmony and repetition, and carried types of plant motifs such as plant branchestriangular leaves- arabesques, lotus and plum flowers, and Chinese Ruyi motifs.

The ceramic of the Niujie collection was marked and decorated with multiple patterns such as floral, plum, lotus, Ruyi, and geometric motifs. The Chinese Muslim artist applied some of the traditional Chinese motifs and blended it with the Islamic decoration and text to serve not only Muslims communities in China but also to serve the Islamic world. 


\section{References}

[1] Abd el-Salam, Mohamed, alfunun al'iislamiat fi alsiyn wa'athariha ealaa funun alyaban wakuria- dirasat 'athariat faniyah (Islamic arts in China And Chinese influences in Japan and Korea arts (From 8th to 13th/ 14th -19th) An Archaeological Artistic Study), Ph.D. Dissertation, Faculty of Arts, Helwan University, Egypt, 2018.

[2] Al- Marwazi, Sharaf Al-Zaman Taher (d. 1124-1125), Kitāb Tabā'i al-Hayawān (the chapters of China and India and leave criticism in his book Natures animal), London, 1942.

[3] al-Muraikhi, Saif, Eajayib Aldunya Waqias Albuldan li Sulaiman al-Tajir (Wonders of the world and measure countries by Sulaiman al-Tajir), Zayed Center for Heritage and Culture, al-Ain, 2005.

[4] al-Nuwayri, Shihāb al-Dīn Ahmad bin 'Abd al-Wahhāb (d. 1333), The Ultimate Ambition in the Arts of Erudition: A Compendium of Knowledge from the Classical Islamic World, New York: Penguin Books, 2016.

[5] al-Sheikha, Abd- Al Khaliq, altaathirat almukhtalifat ealaa al khazf al'iislamii fi aleasr almamliwki (648-923/1250-1517) dirasat 'athryt faniyat muqarnat ( Different influences on Islamic Ceramics in the Mamluk Era (648-923 AH / 1250-1517 AD) Comparative Archaeological Study), Master Dissertation, Faculty of Archaeology, Cairo University, 2002.

[6] al-Wakil, Fayza, "dirasat lituhif khazfiatan waburunziatan dhat kitabat earabiat min 'usrat manj alsiyniat tanshur li'awal mara" (A study of ceramic and bronze antiques with Arabic inscriptions from the Chinese Ming Dynasty First published), Journal of General Union of Arab Archaeologists, Vol 11, pp. 173-208.

[7] Bartók, Mira; Ronan, Christine. Ancient China. Good Year Books, 1994.

[8] Brindley, G.; Robinson, K., "The structure of kaolinite”, Mineralogical Magazine, (1946), vol. 27, no. 194, pp. 242-253.

[9] Cai, Zong-qi, How to read Chinese poetry: A guided anthology. New York: Columbia University Press, 2008.

[10] Chenxue Lin, "mingdai huanguan yu zhenghe xia xiyang de guanxi”" (Relations with the Ming Dynasty eunuch Zheng He's Voyages), Journal of the Institute of Chinese Culture, 2008, No. 48, pp. 163-192.

[11] Chou, Fong, "Symbolism in Chinese Porcelain: The Rockefeller Bequest", The Metropolitan Museum of Art Bulletin, 1962, Vol. 21, No. 01, pp. 12-24.

[12] Cooper, Emmanuel, 10,000 Years of Pottery, 4th ed., 2010, University of Pennsylvania press, 2010.

[13] Cresswel, John, alkhazf alsiyniu watathiruh ealaa algharb (Blue and White Chinese Porcelain and Its Impact on the Western World), translated by Al-Mohandes, Mohamed A., Dar al-kitab al-Arabi, Damascus, 1998.

[14] Cresswel, John, alkhazf alsiyniu watathiruh ealaa algharb (Blue and White Chinese Porcelain and Its Impact on the Western World), translated by Al-Mohandes, Mohamed A., Dar al-kitab al-Arabi, Damascus, 1998.

[15] Denny, Walter, "Blue-and-White Islamic Pottery on Chinese Themes", Boston Museum Bulletin, 1974, vol. 72, No. 368, pp. 76-99.

[16] Deydier, Christian, Understanding Ancient Chinese Bronzes, Their Importance in Chinese Culture, Their Shapes, Functions and Motifs, 2015.

[17] Dillon, Michael, mukhtasir tarikh alsiyn (Brief History of China,), translated by Mohammed, Nancy, Al Arabi Publishing and Distributing, Cairo, 2018. 
[18] Dreyer, Edward, Zheng He: China and the oceans in the early Ming dynasty, 1405-1433, The library of world biography, Pearson Longman, 2006.

[19] Fan Wenjiang, gongyi meishu juan ( Arts and Crafts ), Shaanxi People's Fine Arts Publishing House, 1989.

[20] Finlay, Robert, The Pilgrim Art. Cultures of Porcelain in World History. University of California Press, 2010.

[21] Ford, Barbara; Impey, Oliver, Japanese Art from the Gerry Collection in The Metropolitan Museum of Art, Metropolitan Museum of Art, 1989.

[22] Goffriller, Martin, "Chinese porcelains and the decorations of Omani mihrabs", Proceedings of the Seminar for Arabian Studies, Vol. 45, Papers from the forty- eighth meeting of the Seminar for Arabian Studies held at the British Museum, London, 25 to 27 July 2014 (2015), pp. 123-138.

[23] Goodyear, J., "An X-ray examination of an exceptionally well crystallized kaolinite", Mineralogical Magazine, 1961, vol. 32, No. 254, pp. 902-907.

[24] Hagras, Hamada, "The Ming Court as patron of the Chinese Islamic architecture: The case study of the Daxuexi Mosque in Xi'an", Shedet: Journal of the Faculty of ArchaeologyFayoum University, Vol. 6, 2019, pp. 134-158.

[25] Hagras, Hamada, "Xi'an Daxuexi Alley Mosque: Historical and Architectural Study", EJARS: Egyptian Journalof Archaeological and Restoration Studies, Vol. 9, No. 1, 2019, pp. 97-113.

[26] Hagras, Hamada, Almasajid al'thrīat al baqīat fì madīnat beijīn mundh alqarn alrrab alhijrī (al'shīr almīladī) wahatay nihayat alqarn althalīth 'shr alhijrī (alttas "shr almīladī) "drasat 'athriat muemariat" (Beijing Monumental Mosques Since the fourth century until the Nineteen century A.D. 'architectural and archaeological study'), (Ph.D. diss), Egypt: University of Fayoum, 2016.

[27] Hansman, John, Julfār, an Arabian Port: Its Settlement and Far Eastern Ceramic Trade from the 14th to the 18th Centuries, Psychology Press, 1985.

[28] Hassan, Zaki, Funun al-Islam (The arts of Islam), Dar al-Fekr al-Arabi, Cairo, 1990.

[29] Hassan, Zaki., al-Siyn wafanun al-Islam (China and the arts of Islam), Hindawi Organization, Cairo, 2014.

[30] Heinrich, Sally, Key into China, Curriculum Press, 2007.

[31] Hejing Jing; Ge Xiao, "xinjiang kashen xiang fei mu zhuzi wenshi yishu" (Decorative Arts of Pillars of Xiāngfēi Tomb in Kashgar), Hetian shifan zhuanke xuexiao xuebao (Journal of Hetian Teachers College), 2010, Vol. 4, No. 66, pp. 215-216.

[32] Hsu, Wen-Chin, "Social and Economic Factors in the Chinese Porcelain Industry in Jingdezhen during the Late Ming and Early Qing Period, ca. 1.620-1683", The Journal of the Royal Asiatic Society of Great Britain and Ireland, No. 1 (1988), pp. 135-159.

[33] Hung-Wei, , Tse, chuantong wenshi yingyong yu dangdai qingshaonian ci wenhua tuyang sheji zhi yanjiu yi yun wen ji Ruyi wen wei li (Traditional Ornament Graphic Designs of Cloud Pattern and Ruyi Pattern in Contemporary Young Sub-Culture), Master dissertation, Graduate Institute of Design, Chaoyang University of Technology, 1998.

[34] Husayn, Mahmud, Alkhazf al'iislamii fi misr (Islamic ceramics in Egypt), Dar Gharib Lilnashr, Cairo, 2010.

[35] Ibn al-Faqih, Ahmad ibn Mohammad al-Hamadhani (10 $0^{\text {th }}$ century), Kitāa Al-Boldān (Book guide of countries), edit by Youssef al-Hady, Beirut 1996. 
[36] Ibn Battuta (d. 1369), The Travels of Ibn Battuta: In the Near East, Asia and Africa, translated by Samuel Lee, Cosimo Inc., New York, 2010.

[37] Ibn Khordadbeh, Abu al-Qasim (d. 912 AD), Kitab Al-Masalik wa al-Mamalik (Book of the Roads and Kingdoms), edited by De Goeje, M.J., Publications of the Institute for the History of Arabic-Islamic Science, Frankfurt, 1992.

[38] Kelun, Chen, Chinese porcelain: Art, elegance, and appreciation, San Francisco: Long River Press, 2004.

[39] Kelun, Chen, Chinese Porcelain: Art, Elegance, and Appreciation, San Francisco: Long River Press, 2004.

[40] Kerr, Rose; Needham, Joseph; Wood, Nigel, Science and Civilisation in China, Volume 5, Chemistry and Chemical Technology, Part 12, Ceramic Technology, 2004, Cambridge University Press.

[41] Kessler, Adam, Song Blue and White Porcelain on the Silk Road, BRILL, 2012.

[42] Kubiak, Wladyslaw; Scanlon, George, " Fusțât Expedition: Preliminary Report, 1966", Journal of The American Research Center in Egypt, 1973, vol. 10, pp. 11-25.

[43] Laufer, Berthold, "Chinese Muhammedan Bronzes, with a Study of The Arabic Inscriptions by Martin Sprengling”, Ars Islamica, 1934, Vol.1, No. 2, pp. 133-147.

[44] Li Ganlang, taiwan gu jianzhu tujie shidian (Graphic Code of Ancient Architecture in Taiwan), Yanliu Press, 2003.

[45] Li, Zhiyan; Cheng, Wen, Chinese Pottery and Porcelain, Foreign Languages Press, 1996.

[46] Lion-Goldschmidt, Daisy, La Porcelaine Ming, Fribourg, Office du livre, 1978.

[47] Liu Liangyou, taoci: song. yuan. ming. qing ( Ceramics: Song. Yuan. Ming. Qing), Youshi wenhua Shiyegongsi, 1992.

[48] Liu Rushui, Song yuan ming qing ciqi jianshang (Appreciation of Song, Yuan, Ming and Qing Porcelain), Wunan book Publishing co, 2004.

[49] Ludi Min; Wang Daye, zhongguo gudai yejin yu jin zhu wenwu (Chinese Ancient Metallurgy and Metal Artifacts), Shaanxi Science and Technology Publishing House, 1998.

[50] Luo Aili, shiwu-shiliu shiji de huihui wen yu zhongguo yisilan jiao wenhua yanjiu (Research on Palindrome and Chinese Islamic Culture from the 15th to the 16th Century), Taibei, Wenshizhe Press, 2008.

[51] Macintosh, D., Chinese Blue and White Porcelain, 3rd ed., 1994, Antique Collectors' Club.

[52] Maming Da, "beijing sanli he ming ke,-chongxiu qingzhensi bei jillchutan, lue lun mingdai huanguan qunti zhong de yisilan jiaotu" (Reconstruction Inscriptions of Sanlihe Mosque, Eunuchs of Ming Court Activities), Huizu yanjiu (Journal of Chinese Hui Muslim Studies),2011, No. 83, pp. 38-44.

[53] Marzouq, Mohammed, al funun al zakhrufiat al islamiya fi aleasr aleuthmanii (Islamic decorative arts during Ottoman period), General Egyptian Book Organization, Cairo, 1974.

[54] Medley, Margaret, The Chinese Potter: A Practical History of Chinese Ceramics, 3rd edition, 1989.

[55] Osborne, Harold, The Oxford Companion to the Decorative Arts, 1975, OUP.

[56] Pohl, Walter, Economic geology: principles and practice: metals, minerals, coal and hydrocarbons - introduction to formation and sustainable exploitation of mineral deposits. Chichester, West Sussex: Wiley-Blackwell, 2011.

[57] Quenzer, Jörg; Bondarev, Dmitry; Sobisch, Jan-Ulrich, Manuscript Cultures: Mapping the Field, Walter de Gruyter GmbH \& Co KG, 2014. 


\section{Chinese Islamic Ceramics at the Museum of Niujie Mosque "An analytical Study"}

[58] Rawson, Jessica. The British Museum Book of Chinese Art, (2 $2^{\text {nd }}$ edition), British Museum Press, 2007.

[59] Rezania, Pedram, "Symbol of Lotus in Ancient World", Life Science Journal, 2011, vol. 03, pp. 309-312.

[60] Scanlon, George, "Mamluk Pottery: More Evidence from Fusta", Muqarnas, 1984, vol. 2, pp. 115-126.

[61] Shirazi, Saadi (d. 1291-1292), The Gulistan (The Flower Garden), translated by Alforati, M., The Syrian General Organization Of Books, Damascus, 2012.

[62] Steinhardt, Nancy, "China's Earliest Mosques", Journal of The Society of Architectural Historians, 2008, vol. 67 , No .3, pp. 330-361.

[63] Sulaiman al-Tajir (9 ${ }^{\text {th }}$ century); Abu Zayd al-Sirafi (d. 920), 'akhbar rihlat alearab walfiras 'iilaa alhind walsiyn fi aljughrafiat al'iislamiati (News of Arab and Persian Travels to India and China in Islamic Geography), Volume 164, Publications of the Institute for the History of Arab and Islamic Sciences, Frankfurt, 1994.

[64] Te-k'un, Cheng, Studies in Chinese ceramics, Hong Kong: Chinese University Press, 1984.

[65] Temple, Robert, The Genius of China: 3,000 Years of Science, Discovery, and Invention, (3rd edition). London: André Deutsch, 2007.

[66] Tong Xun, Yīsīlán jiào yǔ běijīng qīngzhēnsì wénhuà (Mosques and Islamic Culture in Beijing), Beijing: Zhongyang Minzu University Press, 2003.

[67] Uthman, M., madinat Dhofar bisaltanat eamman "drrast tarikhiatan 'athriat muemari" (Dhofar City, Sultanate of Oman, "An Archeological and Architectural Historical Study"), 1st ed, Alexandria: Dar Al-Wafa Dunia for Printing and Publishing, 2000.

[68] Uthmān, Shawqi A., Tijärat al-Muhit al-Hindi fi Asr al-Siyāda al-Islāmiyya (41-904/6611498) (Trade of the Indian Ocean in the Era of Islamic Sovereignty (41-904 AH / 661-1498 AD), Kuwait: Al-Majles al-Watani lil-Thaqafa, 1990.

[69] Vainker, S.J., Chinese Pottery and Porcelain, British Museum Press, 1991.

[70] Wahby, Ahmed, Islamic Architecture in China, Mosques of Eastern China, Master's Degree, The American University in Cairo, School of Humanities and Social Sciences, 2000.

[71] Welch, Patricia, Chinese art: a guide to motifs and visual imagery, North Clarendon: Tuttle Publishing, 2008.

[72] Weng Yuwen, "zhenzhu de zhuisui zhe: Ming wuzong ji qi guan yao huihui wen qimin" (The Follower of Allah: Ming Wu-tsung and the Ceramics with Huihui Characters of the Cheng-te Official Kiln), Gugong xueshu jikan (Academic Quarterly of the Palace Museum), vol. 29, no. 2, pp. 147-222.

[73] Wood, Nigel, Chinese Glazes: Their Origins, Chemistry, and Recreation, University of Pennsylvania Press, 1999.

[74] Zhangyong Mei, "alabo-yisilan zhuangshi yishu feng ge yu zhongguo wai shao ci" (Islamic Decorative Styles on Chinese Porcelain), Wenbo Journal, 2003, no.1, pp. 34-50.

[75] Zhongguo lishi bowuguan (Chinese History Museum,), jianming zhongguo wenwu cidian (Concise Chinese Cultural Relics Dictionary), Fujian People's Publishing House, 1991. 